\title{
Trophic ecology of Lontra longicaudis (Carnivora, Mustelidae) in lotic and semilotic environments in southeastern Brazil
}

\author{
Lívia B. Santos; Nelio R. dos Reis \& Mário L. Orsi
}

Universidade Estadual de Londrina, Rodovia Celso Garcia Cid, PR-445, Km 380, Caixa Postal 6001, 86051-980, Londrina, PR, Brasil. (liviabertolla@yahoo.com.br; nrreis1@yahoo.com.br; orsi@uel.br)

\begin{abstract}
Lontra longicaudis (Olfers, 1818) (Carnivora, Mustelidae) is a semi-aquatic animal spread through the Central and South America, except in Chile. The implantation of a hydroelectric power plant along a river alters the dynamics of the watercourse, transforming a lotic environment into a lentic or semilotic one, what can damage the otter's feeding. From April 2008 to March 2009 we analysed the otter's food habits in lotic (streamlet) and semilotic (hydroelectric reservoir) environments of Paranapanema Valley, in southeastern Brazil. Aiming to compare the otter's diet of these two environments, we analyzed statistically the frequency of occurrence of main items in the scats. Fishes represent the base of the diet both in the reservoir and in the streamlet and, despite of the total otter's diet showing up similarities in the two environments, the results evidenced modifications on the fish species consumed between them. In the reservoir the otters ate more exotic fish Oreochromis niloticus (Linnaeus, 1758) probably because it is an easy capture prey in this place. The fact that the otters get established and feed in the reservoir doesn't mean that this structure is benefic to the species because the food supplied for it consists mainly of exotic fish species.
\end{abstract}

KEYWORDS. Neotropical otter, feeding habit, natural environment, changed environment.

RESUMO. Ecologia trófica de Lontra longicaudis (Carnivora, Mustelidae) em ambientes lótico e semilótico no sudeste do Brasil. Lontra longicaudis (Olfers, 1818) (Carnivora: Mustelidae) é um animal semi-aquático com distribuição nas Américas Central e do Sul, exceto no Chile. A implantação de uma usina hidrelétrica em um rio altera a dinâmica do curso d'água, transformando um ambiente lótico em um lêntico ou semilótico, o que pode prejudicar a alimentação das lontras. De abril de 2008 a março de 2009 foi analisado o hábito alimentar das lontras em um ambiente lótico (riacho) e semilótico (reservatório hidrelétrico) no Vale do Paranapanema, sudeste do Brasil. Visando comparar a dieta das lontras nessas duas áreas analisamos estatisticamente a frequência de ocorrência dos principais itens nas fezes. Peixes representaram a base da dieta, tanto no riacho como no reservatório e, apesar da dieta total das lontras ser semelhante entre os dois ambientes, os resultados evidenciaram alterações nas espécies de peixes consumidas entre eles. No reservatório, as lontras se alimentaram em maior quantidade da espécie exótica do peixe Oreochromis niloticus (Linnaeus, 1758), provavelmente, por ser uma presa de fácil captura neste local. O fato das lontras conseguirem se estabelecer e se alimentar no reservatório não significa que essa estrutura seja benéfica para a espécie porque a alimentação ofertada consiste principalmente de espécies de peixes exóticas.

PALAVRAS-CHAVE. Lontra neotropical, hábito alimentar, ambiente natural, ambiente modificado.

The Neotropical Otter, Lontra longicaudis (Olfers, 1818) (Carnivora: Mustelidae), is a semi-aquatic animal found in all countries of Central and South America, except in Chile (Chehébar, 1990; PARera, 1996). The species is classified as "data deficient" in the list of The International Union for Conservation of Nature (IUCN, 2010) and is listed in the Appendix I of the Convention on the International Trade of Endangered Species of Wild Fauna and Flora (CITES, 2008).

The diet is mainly compounded by fish (PARDINI, 1998); crustacean is generally of second importance (Colares \& Waldemarin, 2000; Gori et al., 2003) and mollusc may be present in the diet from some regions (Passamani \& CAMARgo, 1995; Gori et al., 2003). Small mammals, reptiles, amphibians, birds, insects, vegetal materials and fruits are eventually ingested (PARERA, 1993; Quadros \& Monteiro-Filho, 2000).

Due to its strong dependence of a terrestrial environment adjacent to a water body, the otter may be affected both by negative changes in water quality and in the characteristics of the margins (FOSTER-TURLEY et al., 1990; Quadros \& Monteiro-Filho, 2002; Kasper et al., 2004). The construction and operation of hydroelectric power plant affect the biotic and abiotic components by altering the dynamics of the aquatic environment, transforming a lotic environment into a lentic or semi- lentic one (McCARTNeY et al., 2001). In that case, the prey communities are affected and the species adapted to lentic or semi-lotic environments are favored, which may affect, direct or indirectly, the otter feeding (KRUUK, 1995). Because of the inexistence of studies with this species on this kind of habitat and because of the possible changes in the feeding of $L$. longicaudis due to the negative impacts caused in the prey communities by the formation of a reservoir, this study becomes scientifically relevant.

The survey about its feeding habit is commonly performed through the feces analysis (Medina, 1998; Colares \& Waldemarin, 2000; Trites \& Joy, 2005; Quintela et al., 2008). Since they present function of scent marking, they are deposited in visible locations in the environment (KruuK, 1991; Macías-Sanchez \& Aranda, 1999), and Quadros \& Monteiro-Filho (2002) suggested that the regular removal of scats doesn't modify the marking behavior by the animal because this proceeding may be compared to the natural effects caused by the rain or tide washing of scats.

The hypothesis that conduces to present study is that the diet of $L$. longicaudis differs in a lotic (streamlet) and a semilotic (reservoir) environment due to this place's physics and biotic factors being different from the natural conditions. 


\section{MATERIALS AND METHODS}

Study areas. The study was carried out in two areas: Canoas I reservoir (states of São Paulo and Paraná) and Sapé streamlet (state of São Paulo) (Fig. 1).

Canoas I reservoir $\left(50^{\circ} 31^{\prime} \mathrm{W}\right.$ and $\left.22^{\circ} 56^{\prime} \mathrm{S}\right)$, whose power plant operates since 1998, is located in Paranapanema river (micro-basin of Middle Paranapanema), in the border of states of São Paulo and Paraná (Southeast and South regions of Brazil), between the power plants of Canoas II and Capivara and, between the cities of Cândido Mota (state of São Paulo) and Itambaracá (state of Paraná). The reservoir occupies an area of $30.85 \mathrm{~km}^{2}$, with mean width of 300 $\mathrm{m}$ and maximum depth of $5 \mathrm{~m}$ at a region of $351 \mathrm{~m}$ above sea level (DuKe ENERgy BrasiL, 2008). As the reservoir operates in thread of water, that is, it produces energy with the river's water flux accumulating little or any water; it is considered a semi-lotic environment. Reservoir's bed is sandy, with rock outcrops, and the margins are occupied by pasture with predominance of grass and herbaceous plants as Hyparrhenia rufa (Ness) Stapf and remnants of native vegetation from the Seasonal Semideciduos Forest. In the total studied stretch $(10 \mathrm{~km})$ there are three different sections aquaculture activities of Oreochromis niloticus (Linnaeus, 1758), with total extent of $2.4 \mathrm{~km}^{2}$ of net tanks nearly.

The Sapé streamlet is located about $47 \mathrm{~km}$ from Canoas I reservoir $\left(50^{\circ} 34^{\prime} 35^{\prime \prime} \mathrm{W}\right.$ and $\left.22^{\circ} 24^{\prime} 53^{\prime \prime} \mathrm{S}\right)$, situated in the Southeast region of state of São Paulo, in the city of Paraguaçu Paulista. This streamlet belongs to the micro-basin of Middle Paranapanema river and to the sub-basin of Capivara river, comprising an area of 3.971 $\mathrm{km}^{2}$, with mean width of $3 \mathrm{~m}$. It flows into Capivara river, which flows into Paranapanema river, thus, there is no direct connection between the two studied locations. The bed of the streamlet is mostly sandy with areas of rapids and bottom of gravel and pebbles in the upper reaches. The riparian vegetation, ecotone between Cerrado type and Stational Semidecidual Forest, is preserved in most part of the streamlet.

Sampling and data analysis. Between April 2008 and March 2009, the studied areas were visited every fifteen days, totaling 24 visits in each location. One stretch with $10 \mathrm{~km}$ was covered in both margins of the streamlet and the reservoir searching locals with deposit of feces from L. longicaudis. The feces were identified as belonging to the species based on the shape, size, characteristic odor and footprints or associated mucus (Murie, 1974).

Each sample was gathered using plastic bags and preserved in alcohol $70 \%$ until they were washed over a thin mesh sieve $(0.1 \mathrm{~cm})$. The washed feces were dried up naturally. After that, using tweezers, the remaining structures were separated by classifying them according to the following food items: fish, crustacean, mollusc, insect, mammal, bird, amphibian, reptile, leaf and fruit, based on previous studies (HELDER-José \& KER

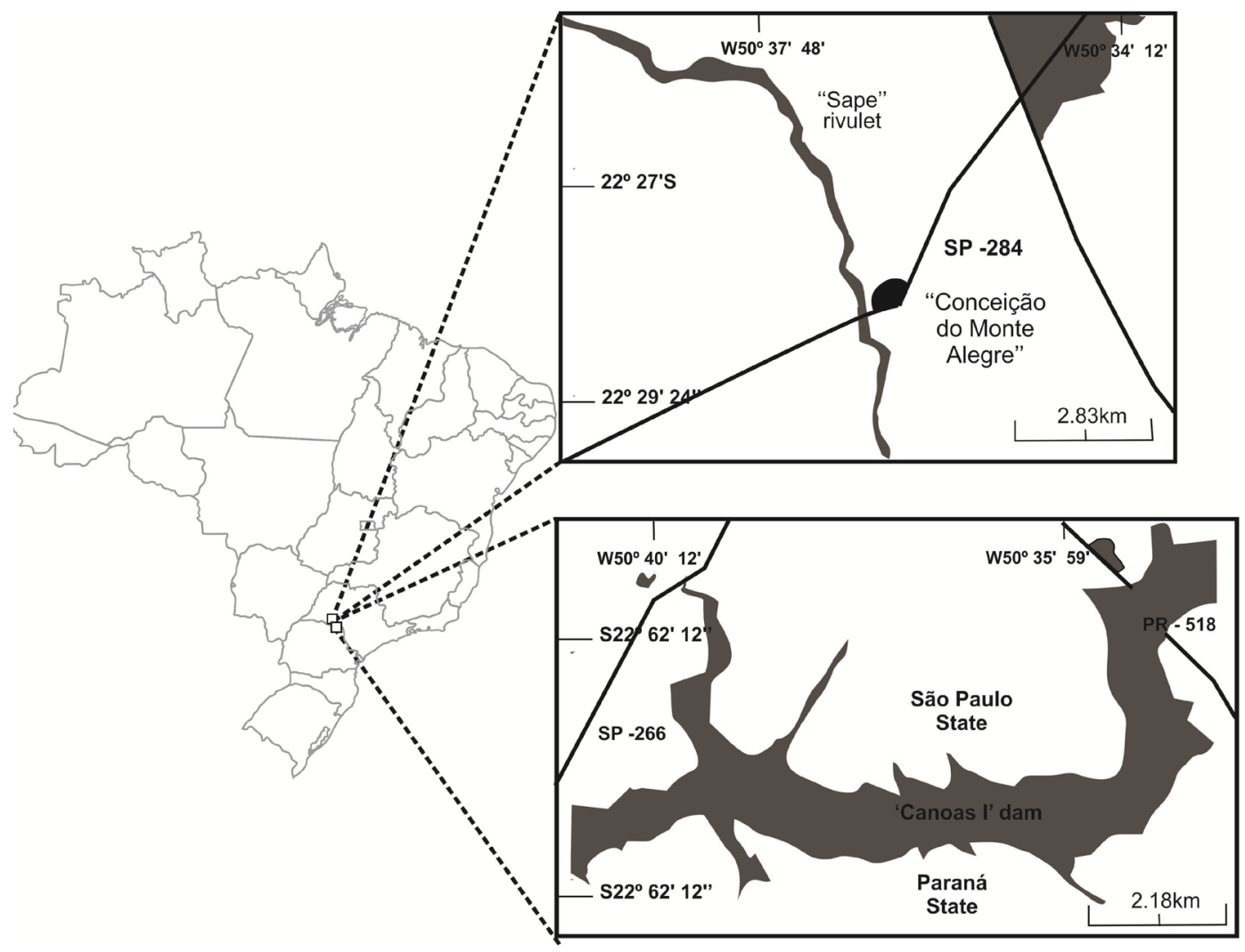

Fig. 1. Location of the sampling stations in Sapé streamlet, state of São Paulo (above to the right) and in the reservoir Canoas I, states of São Paulo and Paraná (below to the right). 
DE Andrade, 1997; Quadros \& Monteiro-Filho, 2000; GoRi et al., 2003; Quintela et al., 2008). Moreover, from the structures, the order, family or species were identified, whenever possible.

The fragments of fish, insect and fruit were identified by specialists from the Universidade Estadual de Londrina (UEL) and compared with their zoological collection of it; molluscs were identified by specialist from the Universidade Estadual de Maringá (UEM). The hair found in the feces was identified through preparation and cuticle analysis under stereoscopic microscope using methodology and identification keys from QuAdros \& Monteiro-Filho (2006a, b). The bones from bird, reptile and amphibian were compared with literature (Romer \& PARsOns, 1985; KARDONG, 2002); however, these groups could not be identified at lower levels only by the analysis of the bone or feather.

The frequency of occurrence (FO) was estimated for each group and species identified in the samples and was expressed in percentage (Medina, 1998; Colares \& Waldemarin, 2000; KASPER et al., 2004). The FO (number of times that the item occurred in the samples divided by the total number of samples) of each group can exceed $100 \%$ because more than one especies of the same group can appear in a single sample.

The ANOVA (one way) test has also beens carried out to compare the total abundance of the otter's feeding groups between the two environments. And the Morisita-Horn index $\left(\mathrm{C}_{\mathrm{H}}\right.$ MorisitA, 1959) was used to verify the similarity between reservoir and streamlet as for the general diet of otters and the same index was accomplished to compare the similarity of the each alimentary groups consumed by otters in the study areas:

$$
C_{H}=\frac{\left(2 \sum X_{i j} X_{i k}\right)}{\left[\left(\sum X_{i j}^{2} / N^{2}\right)+\left(\sum X_{i j}^{2} / N^{2}\right)\right] N_{j} N_{k}}
$$

Where:

$\mathrm{C}_{\mathrm{H}}=$ Morisita-Horn similarity index;

$\mathrm{X}_{\mathrm{ij}}, \mathrm{X}_{\mathrm{ik}}=$ individuals number of the species $\mathrm{i}$ in the sample $\mathrm{j}$ and in the sample $\mathrm{k}$, respectively;

$\mathrm{N}_{\mathrm{j}}, \mathrm{N}_{\mathrm{k}}=$ total individuals number of the sample $\mathrm{j}$ and of the sample $\mathrm{k}$, respectively.

The trophic breadth of the species was estimated through the standardized Levins' index $\left(\mathrm{B}_{\mathrm{A}}\right.$; KREBS, 1989):

$$
B_{A}=\frac{\left[\frac{1}{\sum p_{j}^{2}}\right]-1}{n-1}
$$

Where:

$\mathrm{B}_{\mathrm{A}}=$ Levins' index;

$\mathrm{p}_{\mathrm{j}}=$ proportion of $\mathrm{FO}$ of the item $j$ in the diet and $n$ is the total number of food resources used by the species; $\mathrm{n}=$ number of samples that item $j$ appear in the diet.

Diet diversity, obtained from the Shannon-Wiener index (H'; SмIтн, 1980), was calculated separately for each group of prey in order to incorporate the sum of the contributions of the individual item to the total in the diet:

Where:

$\mathrm{H}^{\prime}=$ Shannon-Wiener index;

$\mathrm{S}=$ number of individuals in each group;

$\mathrm{p}_{\mathrm{i}}=$ proportion of the number of individuals from one group in relation to the total number of individuals in the samples.

Afterwards, we employed a $t$-test to compare the feeding diversity in the two environments.

$$
H^{\prime}=-\sum_{i=1}^{S} p_{i} \ln p_{i}
$$

\section{RESULTS}

We analyzed 400 samples of feces around the reservoir and 146 samples along the streamlet, despite the same field effort.

The most important feeding group in otter's diet in the reservoir was fish followed by the mollusc and insect; in the streamlet, the most consumed group was also fish, but secondary items in the diet were crustacean and insect (Fig. 2).

Among the fishes, an exotic species of Cichlidae - Oreochromis niloticus - was the most consumed by otters in the reservoir $(56.5 \%)$, while the native species Apareiodon sp. (Eigenmann, 1916) and Cichlasoma paranaense (Kullander, 1983) were the most consumed in streamlet with $50.68 \%$ and $34.25 \%$, respectively (Fig. 3).

As for the orders and families of the other prey groups, the otters didn't show apparent difference in consumption between the two environments (Tab. I).

The ANOVA test didn't show significant difference $(p>0.05)$ between the environments as for total abundance of the groups consumed by otters.

The Morisita-Horn similarity index indicated

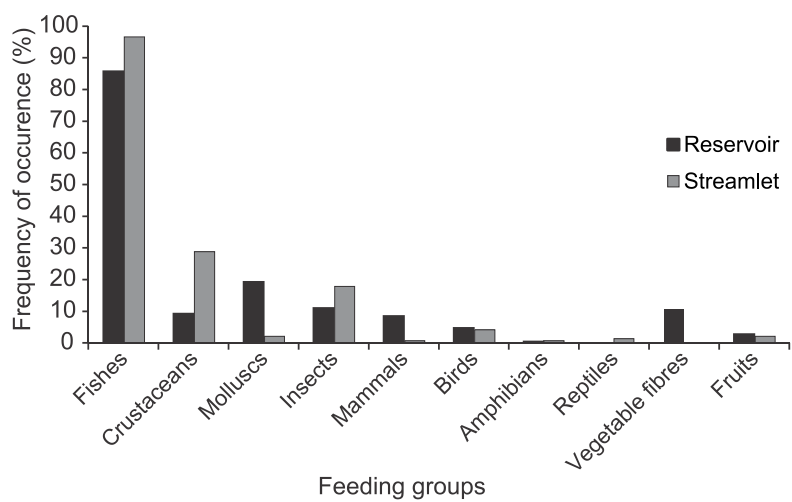

Fig. 2. Frequency of occurrence of the otter's feeding groups in the reservoir Canoas I, states of São Paulo and Paraná (black bars) and in the Sapé streamlet, state of São Paulo (grey bars). 
high resemblance $\left(\mathrm{C}_{\mathrm{H}}=0.9\right)$ between the reservoir and the streamlet as for total otter's diet and in its analyses for feeding item showed low similarity $\left(\mathrm{C}_{\mathrm{H}}=0.32\right)$ of the diet between the two environments only for the reptile group.

The value of the trophic niche breadth of the species was low in both environments $\left(\mathrm{B}_{\mathrm{A}}=0.182\right.$ for the reservoir; $\mathrm{B}_{\mathrm{A}}=0.125$ for the streamlet), however the diet of the animals in the streamlet presented narrower breadth than in the reservoir.
The diversity index (Shannon-Wiener) of fish, mollusc, mammal and fruit were significantly higher $(\mathrm{p}<0.05)$ in the diet of the otters from the reservoir $\left(\mathrm{H}^{\prime}=2.395 ; \mathrm{H}^{\prime}=2.119 ; \mathrm{H}^{\prime}=1.714 ; \mathrm{H}^{\prime}=1.768\right.$, respectively) than from the streamlet $\left(\mathrm{H}^{\prime}=2.32 ; \mathrm{H}^{\prime}\right.$ $=0 ; \mathrm{H}^{\prime}=0 ; \mathrm{H}^{\prime}=0.636$, respectively). Nevertheless, there were no significant differences in the diversity of the other consumed groups between the two locations.

Tab. I. Occurrence $(\mathrm{O})$ and frequency of occurrence (FO\%) of the species and the category preys consumed by otters in the reservoir Canoas I and in the streamlet Sapé, Southeastern Brazil.

\begin{tabular}{|c|c|c|c|c|c|c|c|}
\hline \multirow[t]{2}{*}{ Food groups } & \multirow[t]{2}{*}{ Order } & \multirow[t]{2}{*}{ Family } & \multirow[t]{2}{*}{ Species } & \multicolumn{2}{|c|}{$\begin{array}{l}\text { Reservoir } \\
(\mathrm{N}=400)\end{array}$} & \multicolumn{2}{|c|}{$\begin{array}{l}\text { Streamlet } \\
(\mathrm{N}=146)\end{array}$} \\
\hline & & & & $\mathrm{O}$ & $\mathrm{FO} \%$ & $\mathrm{O}$ & $\mathrm{FO} \%$ \\
\hline \multirow{25}{*}{ Fishes } & \multirow{11}{*}{ Characiformes } & \multirow{7}{*}{ Characidae } & Acestrorhynchus lacustris (Lütken, 1875) & 32 & 8 & 2 & 1.37 \\
\hline & & & Astyanax sp. & 0 & 0 & 1 & 0.68 \\
\hline & & & Oligosarcus parananensis Menezes \& Géry, 1983 & 1 & 0.25 & 1 & 0.68 \\
\hline & & & Salminus brasiliensis (Cuvier, 1817) & 0 & 0 & 2 & 1.37 \\
\hline & & & Serrasalmus maculatus Kner, 1858 & 1 & 0.25 & 1 & 0.68 \\
\hline & & & Unidentified & 1 & 0.25 & 0 & 0 \\
\hline & & & Leporinus sp. & 20 & 5 & 1 & 0.68 \\
\hline & & \multirow[t]{2}{*}{ Anostomidae } & Schizodon intermedius Garavello \& Britski, 1990 & 2 & 0.5 & 0 & 0 \\
\hline & & & Unidentified & 2 & 0.5 & 0 & 0 \\
\hline & & Prochilodontidae & Prochilodus lineatus (Valenciennes, 1847) & 27 & 6.75 & 21 & 14.38 \\
\hline & & Parodontidae & Apareiodon sp. & 20 & 5 & 74 & 50.68 \\
\hline & \multirow[t]{2}{*}{ Gymnotiformes } & Gymnotidae & & 2 & 0.5 & 0 & 0 \\
\hline & & Pimelodidae & & 1 & 0.25 & 1 & 0.68 \\
\hline & \multirow[t]{2}{*}{ Siluriformes } & Loricariidae & & 6 & 1.5 & 7 & 4.79 \\
\hline & & Unidentified & & 8 & 2 & 0 & 0 \\
\hline & \multirow{8}{*}{ Perciformes } & \multirow{6}{*}{ Cichlidae } & Oreochromis niloticus (Linnaeus, 1758) & 226 & 56.5 & 32 & 21.92 \\
\hline & & & Geophagus brasiliensis (Quoy \& Gaimard, 1824) & 5 & 1.25 & 0 & 0 \\
\hline & & & Cichlasoma paranaense Kullander, 1983 & 26 & 6.5 & 50 & 34.25 \\
\hline & & & Cichla kelberi Kullander \& Ferreira, 2006 & 3 & 0.75 & 0 & 0 \\
\hline & & & Crenicichla sp. & 0 & 0 & 1 & 0.68 \\
\hline & & & Unidentified & 2 & 0.5 & 4 & 2.74 \\
\hline & & Cyprinidae & Cyprinus sp. & 29 & 7.25 & 2 & 1.37 \\
\hline & & Sciaenidae & Plagioscion squamosissimus (Heckel, 1840) & 1 & 0.25 & 1 & 0.68 \\
\hline & Unidentified & & & 9 & 2.25 & 2 & 1.37 \\
\hline & \multirow{6}{*}{ Decapoda } & & TOTAL $^{1}$ & 343 & 85.75 & 141 & 96.57 \\
\hline \multirow{5}{*}{ Crustaceans } & & Palaemonidae & Macrobrachium sp. & 23 & 5.75 & 34 & 23.29 \\
\hline & & Anomura & Aegla sp. & 0 & 0 & 5 & 3.42 \\
\hline & & Trichodactylidae & Trichodactylus sp. & 18 & 4.5 & 7 & 4.79 \\
\hline & & Hyalellidae & Hyalella sp. & 0 & 0 & 1 & 0.68 \\
\hline & & & TOTAL $^{1}$ & 37 & 9.25 & 42 & 28.77 \\
\hline \multirow{6}{*}{ Molluscs } & $\begin{array}{l}\text { Architaenioglossa } \\
\text { (Gastropoda) }\end{array}$ & Ampullariidae & Pomacea sp. & 37 & 9.25 & 1 & 0.68 \\
\hline & $\begin{array}{l}\text { Pulmonata } \\
\text { (Gastropoda) }\end{array}$ & Planorbidae & & 19 & 4.75 & 2 & 1.37 \\
\hline & $\begin{array}{l}\text { Unidentified } \\
\text { (Gastropoda) }\end{array}$ & & & 39 & 9.75 & 1 & 0.68 \\
\hline & $\begin{array}{l}\text { Veneroida } \\
\text { (Bivalvia) }\end{array}$ & Corbiculidae & Corbicula fluminea (Müller, 1774) & 7 & 1.75 & 0 & 0 \\
\hline & Unidentified & & & 5 & 1.25 & 0 & 0 \\
\hline & & & TOTAL $^{1}$ & 77 & 19.25 & 3 & 2.05 \\
\hline \multirow{4}{*}{ Insects } & Odonata & & & 26 & 6.5 & 7 & 4.79 \\
\hline & Blattodea & & & 0 & 0 & 1 & 0.68 \\
\hline & \multirow{2}{*}{ Hemiptera } & Cicadellidae & & 4 & 1 & 1 & 0.68 \\
\hline & & Unidentified & & 5 & 1.25 & 3 & 2.05 \\
\hline
\end{tabular}


Tab. I. Cont...

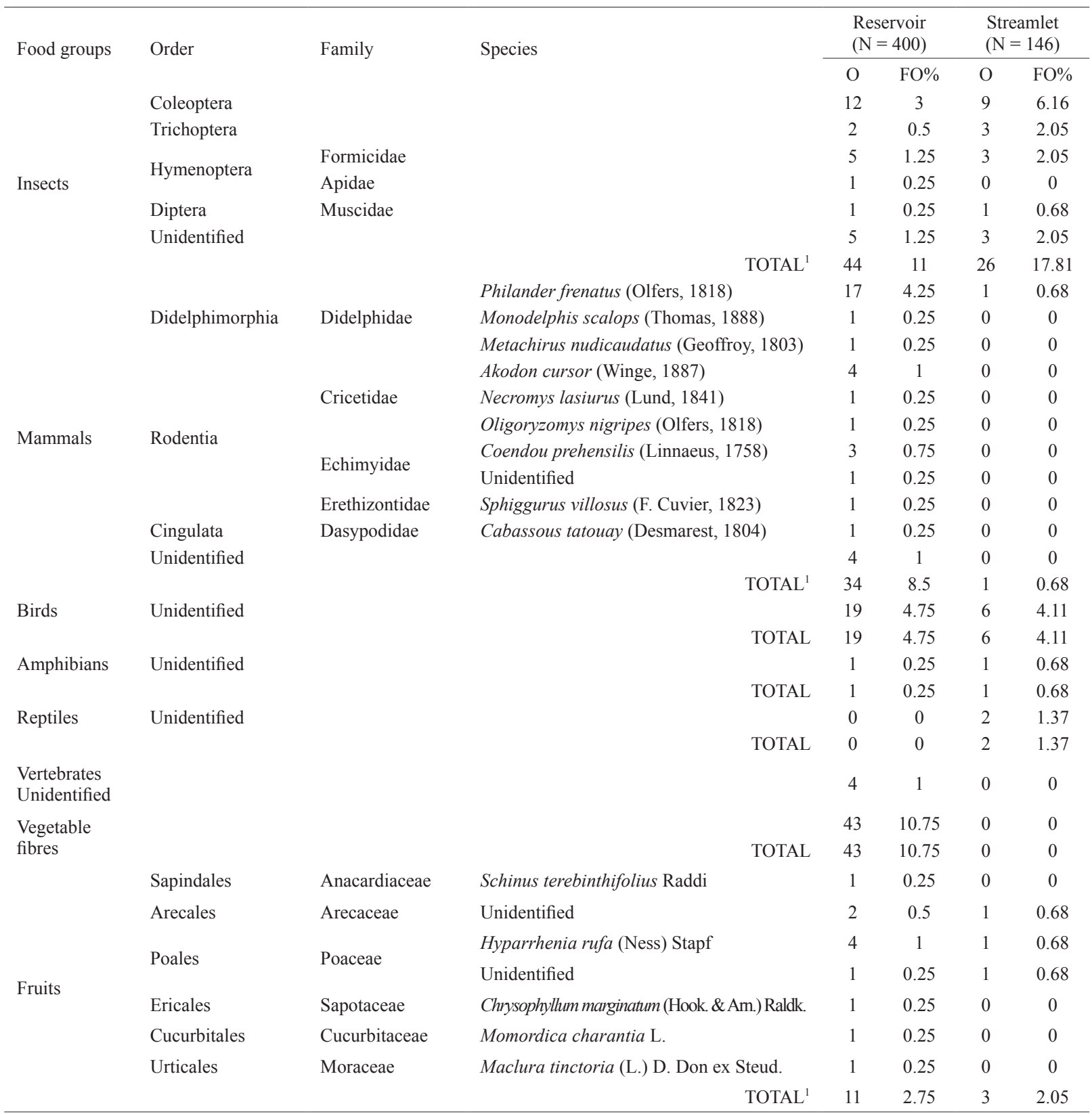

In the total of each food group was considered, both for the occurrences and to the frequency of occurrence, only the number of samples that the group appeared, regardless of the occurrence of more than one species of the group on the same sample.

\section{DISCUSSION}

Fish was the most consumed item, both in the streamlet and in the reservoir, coinciding with the results from other studies such GoRI et al. (2003) in a lake in the Argentina, KASPER et al. (2004) in a river in the state of Rio Grande do Sul and Quintela et al. (2008) in a coastal stream of the state of Rio Grande do Sul.

The fact of the fish species Apareiodon sp., Cichlasoma paranaense, Oreochromis niloticus and Prochilodus lineatus (Valenciennes, 1836) are the most representative in the diet in the streamlet may be explained because they are sedentary life style, detritivorous and live close to the margins (MORIARTY et al., 1973; Hahn et al., 1997; AвelHa et al., 2001; ShiBatTA et al., 2002). These characteristics facilitate the capture by otters (KASPER et al., 2004) implying that they are opportunistic predators and feed on prey species that are less active (ERLINGe, 1968; Adrian \& Delibes, 1987).

In the reservoir, the higher frequency of Oreochromis niloticus in the samples may be explained by high frequency with that these individuals escape from the breeding tanks occupying lentic or semi-lotic waters of the region (Lowe-McConnell, 2000; ShibatTA et al., 2002) and because the consume of this species also occurred directly from the aquaculture tanks and gill nets, as reported by fishermen from the region.

The escape of this non-native fish species of the 


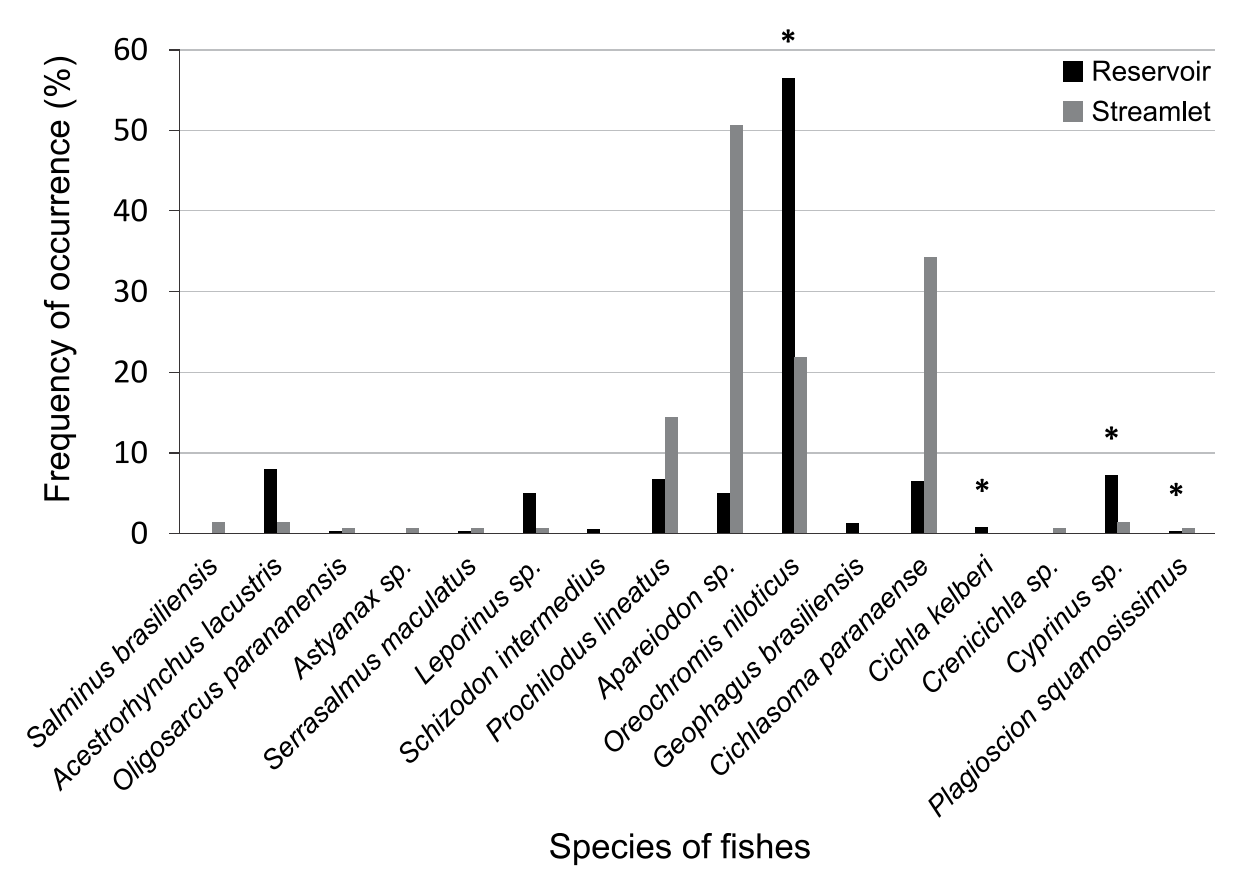

Fig. 3. Frequency of occurrence of fish species consumed by the otters in the reservoir Canoas I, states of São Paulo and Paraná (black bars) and in the Sapé streamlet, state of São Paulo (grey bars) (*, exotic species).

aquaculture tanks in this changed environment can cause degradation and exclusion of native fish species and changes in communities and ecosystem structure (BRITTON \& ORSI, 2012), affecting directly or indirectly the otter's diet. Moreover, the frequency of this exotic fish species in otter's diet in the reservoir is higher than in the streamlet, a sign of potential impact for their food habits.

The high consumption of crustaceans in the streamlet corroborates with the results of other studies (Helder-José \& Ker de Andrade, 1997; Pardini, 1998; Macías-Sanchez \& Aranda, 1999; Quintela et al., 2008). The most frequent crustacean in the diet was Macrobrachium sp. probably due to the ease of being captured, since it lives next to the margins and in current with gravel bottom and less deep water (MACÍAS-SANCHES \& ARANDA, 1999).

The relatively high consumption of mollusc by otters in the reservoir may be related to the greater amount of organic matter and aquatic vegetation, which favored the group colonization (BofFI, 1979). Moreover, probably, the predators may visualize them more easily in the bottom from lentic stretches. Gori et al. (2003), in Ibera lake, Argentina, observed the great importance of mollusc in the diet of L. longicaudis in this type of environment. Probably the group might have been underestimated both in the streamlet and in the reservoir, because only pieces of shells from some representatives of Gastropoda and Bivalvia were observed in the feces. Other molluscs might have been ingested, but they were not verified because the otters present the habit to ingest only the soft parts and to discard the shells and valves (PARERA, 1993).

The high frequency of insects in the diet of the species, mainly the aquatic ones, has already been reported by several authors (HELDER-José \& KeR DE Andrade, 1997; Colares \& Waldemarin, 2000; Gori et al., 2003; Quintela et al., 2008). The most consumed orders of insects were Odonata and Coleoptera in both environments.

Mammal, bird, amphibian and reptile appeared in low percentage in the otter's diet in both locations, corroborating with the results of HeLDER-José \& Ker de Andrade (1997), Pardini (1998), Colares \& Waldemarin (2000), Quadros \& Monteiro-Filho (2001), KASPER et al. (2004) and Quintela et al. (2008).

Although vegetable fibre has been consumed by the otters only in the reservoir and the diversity of fruits species in their feeding has been higher in this location, these feeding groups present a too low FO in the diet, confirming their just opportunistic consume.

As evidenced by the statistical analyses (ANOVA and Morisita-Horn index), in the generality, the otter's diet remained similar between the natural and changed environments. Whereas RodRíGUEZ-JoRquera \& SEPÚlvedA (2011) found significant differences between rivers or lakes just for crustacean consumed by $L$. provocax (Thomas, 1908) in Chile, in our study there has been low similarity between the two areas just to the reptile group, when the food items were analyzed separately. This result was probably influenced by the reptile group appearing just in the streamlet samples and with a low FO, which can have caused an inexactitude in the statistical test.

In spite of the similarities observed in the total otter's diet and of fish remaining the base of their feeding in the study areas our results confirm that were substitutions in the fish species consumed between 
the reservoir and the streamlet. These divergences can be explained by the different physical and biological conditions between a lotic environment and a semilotic one, like water depth, water surface, current and differences in prey availability (MedinA, 1998). The high food specialization of the otter highlighted by this and other studies (PARDINI, 1998; KASPER et al., 2004) indicates that this animal select particular types of prey, consuming preferentially species with sedentary and benthic habit.

The higher values of diversity for fish, mollusc, mammal and fruit in the feeding of L. longicaudis observed in the reservoir than in the streamlet are related to the smaller food specialization in that environment than the other, meaning that the food availability is uncertain in the reservoir.

Corroborating with the results found by PEDROSO et al. (2004) with Lutra lutra (Linnaeus, 1758) in large storage dams in Portugal, we can conclude that apparently the otters use the reservoir complementary because it supplies greater easy capture food than the streamlet; nevertheless they depend of a less changed environment, like the tributaries of the reservoir, to shelter and to reproduce. As a matter of fact the otters get established in the reservoir, but this doesn't mean that this structure is benefic to the species because, besides it doesn't provide good quality of refuge and reproduction, the food supplied consists mainly of exotic fish species. This situation may cause unknown impacts to the otters and, therefore, needs to be better investigated.

Acknowledgements. The authors wish to express their gratitude to CAPES for the financial support; to the Programa de PósGraduação em Ciências Biológicas from the Universidade Estadual de Londrina; to Carlos Eduardo de Alvarenga Júlio, Ana Odete Santos Vieira and Sue Ellen Prata Fernandes for the identification of fishes, insects, fruits and molluscs, respectively; to Florisvaldo Bertolla for his helpful review on the manuscript, and to Amadeu and Almeriana for the aid in the field jobs.

\section{REFERENCES}

Abelha, M. C. F; Agostinho, A. A. \& Goulart, E. 2001. Plasticidade trófica em peixes de água doce. Acta Scientiarium 23(2):425-434.

Adrian, M. I. \& Delibes, M. 1987. Food habits of the otter (Lutra lutra) on two habitats of the Doñana National Park, SW Spain. Journal of Zoology 212:399-406.

Boffi, A. V. 1979. Moluscos Brasileiros de interesse médico e econômico. São Paulo, HUCITEC. 376p.

Britton, J. R. \& Orsi, M. L. 2012. Non-native fish in aquaculture and sport fishing in Brazil: Economic benefits versus risks to fish diversity in the upper River Paraná Basin. Reviews in Fish Biology and Fisheries 22:1-11.

Chehébar, C. 1990. Action Plan for Latin American Otters. In: FosterTurley P.; MacDonald, S. \& Mason, C. eds. Otters: An Action Plan for their Conservation. Switzerland, IUCN Otter Specialist Group, Gland. p.64-73.

CITES (Convention on International Trade in Endangered Species of Wild Fauna and Flora). 2008. CITES species database, Appendices I, II and III. Available at: <http://www.cites.org/ eng/app/appendices.html $>$. Accessed on: 18.01.2010.

Colares, E. P. \& Waldemarin, H. F. 2000. Feeding of the Neotropical river otter (Lontra longicaudis) in the coastal region of the Rio Grande do Sul State, Southern Brazil. IUCN Otter Specialist Group Bulletin 17(1):6-13.
Duke Energy Brasil. 2008. Duke Energy Brasil, Canoas I. Available at: <http://www.duke-energy.com.br/usinas/uhe_canoas_I.asp>. Accessed on: 26.05.2009.

ERLinge, S. 1968. Food studies of captive otter (Lutra lutra L.). Oikos 19:259-270.

Foster-Turley, P.; MacDonald, S. \& Mason, C. 1990. Otters: an action plan for their conservation. Cambridge, IUCN. 126p.

Gori, M.; Carpaneto, G. M. \& Ottino, P. 2003. Spatial distribution and diet of the Neotropical otter Lontra longicaudis in the Ibera Lake (northern Argentina). Acta Theriologica 48(4):495-504.

Hahn, N. S.; Andrian, I. F.; Fugi, R. \& Almeida, V. L. L. 1997. Ecologia trófica. In: Vazzoler, A. M. M; Agostinho, A. A. \& Hahn, N. S. eds. A planície de inundação do Alto rio Paraná: aspectos físicos, biológicos e sócio-econômicos. Maringá, EDUEM. p.209-228.

Helder-José \& Ker de Andrade, H. 1997. Food and feeding habits of the Neotropical river otter Lontra longicaudis (Carnivora, Mustelidae). Mammalia 61(2):193-203.

IUCN (International Union for the Conservation of Nature and Natural Resources). 2010. IUCN Red List of Threatened Species, version 2. Available at: <http://www.iucnredlist.org $>$. Accessed on: 08.01.2010.

Kardong, K. V. 2002. Vertebrates: Comparative Anatomy, Function, Evolution. 3ed. New York, Mc Graw Hill. 784p.

Kasper, C. B.; Feldens, M. J.; Salvi, J. \& Grillo, H. C. Z. 2004. Estudo Preliminar sobre a ecologia de Lontra longicaudis (Olfers) (Carnivora, Mustelidae) no Vale do Taquari, Sul do Brasil. Revista Brasileira de Zoologia 21(1):65-72.

KreBs, C. J. 1989. Ecological Methodology. New York, Harper Collins Publishers. 12ed. 654p.

KRUUK, H. 1991. Scent marking by otters (Lutra lutra): signaling the use of resources. Behavioral Ecology 3(2):133-139.

1995. Wild otters predation and population. Oxford, Oxford University Press. 290p.

Lowe-McConnell, R. H. 2000. The roles of tilapias in ecosystems. In: Beveridge, M. C. M. \& Mc-Andrew, B. J. eds. Tilapias: Biology and Exploitation. Boston, London, Kluwer Academic Publishers. p.129-162.

Macías-Sanchez, S. \& Aranda, M. 1999. Analisis de la alimentación de la nutria Lontra longicaudis (Mammalia: Carnivora) en un sector del rio de los pescados, Veracruz, Mexico. Acta Zoologica Mexicana 76:49-57.

McCartney, M. P.; Sullivan, C. \& Acreman, M. C. 2001. Ecosystem impacts of large dams. Wallingford, UK, Centre for Ecology and Hydrology. 81p.

Medina, G. 1998. Seasonal variations and changes in the diet of southern river otter in different freshwater habitats in Chile. Acta Theriologica 43(3):285-292.

Moriarty, D. J. W.; Darlington, J. P. E. C.; Dunn, I. G.; Moriarty, C. M \& Tevlin, M. P. 1973. Feeding and grazing in Lake Georgia, Uganda. Proceedings of the Royal Society 184(1076):299-319.

Morisita, M. 1959. Measuring of interespecific association and similarity between communities. Memoirs of the Faculty of Science of Kyushu University, Series E. Biology 3:65-80.

MurIE, O. 1974. A field guide to animal tracks. Boston, Houghton Miffin Company. 375p.

PARDINI, R. 1998. Feeding ecology of the Neotropical river otter, Lontra longicaudis, in an Atlantic Forest Stream, southeastern Brazil. Journal of Zoology 245(4):385-391.

Parera, A. 1993. The Neotropical river otter Lutra longicaudis population in Ibera lagoon, Argentina. IUCN Otter Specialist Group Bulletin 8:13-16.

1996. Las "nutrias verdadeiras" de la Argentina. Boletin Tecnico de la Fundacion Vida Silvestre Argentina 21:1-38.

Passamani, M. \& Camargo, S. L. 1995. Diet of the river otter Lutra longicaudis in Furnas reservoir, south-eastern Brazil. IUCN Otter Specialist Group Bulletin 12:32-33.

Pedroso, N.; Santos-Reis, M. \& Vasconcelos, L. 2004. O Uso de Grandes Barragens pela Lontra no Alentejo. Revista de Biologia 22:211-224.

Quadros, J. \& Monteiro-Filho, E. L. A. 2000. Fruit occurrence in the diet of the Neotropical otter, Lontra longicaudis, in southern Brazilian atlantic forest and its implications for seed dispersion. Mastozoologia Neotropical 7(1):33-36.

2001. Diet of the Neotropical Otter, Lontra longicaudis, in an Atlantic Forest Area, Santa Catarina State, Southern Brazil. Studies on Neotropical Fauna and Environment 36(1):15-21. 
2002. Sprainting sites of the Neotropical otter, Lontra longicaudis, in an Atlantic Forest area of Southern Brazil. Mastozoologia Neotropical 9(1):39-46.

2006a. Coleta e preparação de pêlos de mamíferos para identificação em microscopia óptica. Revista Brasileira de Zoologia 23(1):274-278.

2006b. Revisão conceitual, padrões microestruturais e proposta nomenclatória para os pêlos-guarda de mamíferos brasileiros. Revista Brasileira de Zoologia 23(1):279-292.

Quintela, F. M.; Porciuncula, R. A. \& Colares, E. P. 2008. Dieta de Lontra longicaudis (Olfers) (Carnivora, Mustelidae) em um arroio costeiro da região sul do Estado do Rio Grande do Sul, Brasil. Neotropical Biology and Conservation 3(3):119-125.

Rodríguez-Jorquera, I. \& Sepúlveda, M. A. 2011. Trophic spatial variations in the Southern river otter, Lontra provocax, in freshwater habitats, Chile. IUCN Otter Specialist Group Bulletin 28(A):70-75.

Romer, A. S. \& Parsons, T. S. 1985. Anatomia Comparativa dos Vertebrados. São Paulo, Atheneu. 559p.

Shibatta, A. O.; Orsi, M. L., Bennemann, S. T. \& Silva-Souza, A. T 2002. Diversidade e distribuição de peixes na bacia no rio Tibagi. In: Medri, M. E.; Bianchini, E.; Shibatta, A. O. \& Pimenta, J. A eds. A bacia do rio Tibagi. Londrina, M. E. Medri. p.403-423.

Sмттн, R.L. 1980. Ecology and Field Biology. New York, Harper \& Row. 3ed. 835p.

Trites, A. W. \& Joy, R. 2005. Dietary Analysis from fecal samples: how many scats are enough? Journal of Mammalogy 86(4):704712 .

Recebido em 30 de junho de 2011. Aceito em 15 de agosto de 2012. ISSN 0073-4721

Artigo disponível em: www.scielo.br/isz 